\title{
The Impact of Rising House Prices on Business Development: Literature Review and Path Analysis
}

\author{
Jun Xie, Li Tan \\ Faculty of Business Administration, South China University of Technology, Guangzhou, China \\ Email: 15521096544@163.com
}

How to cite this paper: Xie, J. and Tan, L. (2018) The Impact of Rising House Prices on Business Development: Literature Review and Path Analysis. Open Journal of Accounting, 7, 73-81.

https://doi.org/10.4236/ojacct.2018.71005

Received: December 22, 2017

Accepted: January 15, 2018

Published: January 18, 2018

Copyright $\odot 2018$ by authors and Scientific Research Publishing Inc. This work is licensed under the Creative Commons Attribution International License (CC BY 4.0).

http://creativecommons.org/licenses/by/4.0/

\section{c) (i) Open Access}

\begin{abstract}
Since the housing reform in 1998, China's real estate market has developed rapidly and real estate prices have been on the rise. The real estate industry has become the pillar industry of our economy. However, historical experience has repeatedly proved that if economic development relies too heavily on real estate and real estate prices continue to rise rapidly and rapidly, it will affect enterprises' investment, production efficiency and innovation ability, which will affect the steady and healthy development of enterprises. Some studies have found that the rise of house prices has adverse effects on the development of non-real estate enterprises such as cost effect, investment transfer effect and credit effect. Therefore, it is necessary to intensify the regulation and control of house prices, vigorously develop long-term public rental housing and improve the dynamic monitoring mechanism of real estate mortgage, limit the flow of credit funds into the real estate.
\end{abstract}

\section{Keywords}

Real Estate Price, Enterprise Investment, Production Efficiency, Innovation Ability

\section{Introduction}

Since the house reform in 1998, China's real estate market has undergone a revolutionary change. Real estate industry has become an important pillar of the national economy. Overall, the development of China's real estate economy presents several characteristics: 1) Large-scale investment and rapid growth: In 2016, the proportion of real estate investment in fixed assets investment in the whole society was $17.2 \%$, and the added value of real estate accounted for $7.3 \%$ 
of GDP, which were respectively $4.5 \%$ and $3.7 \%$ higher than that in $1998 ; 2$ ) High prices and rapid prices rising speed: Housing prices in China's first-tier cities far exceed the reasonable level. Since 1998, housing prices in China have been on the rise for almost 20 years. Only during the SARS in 2003 and during the international financial crisis in 2008, house prices dropped briefly. In the first half of 2017, housing prices in China's first-tier cities are the highest in the world. According to NUMBEO, the price/income ratio of Shenzhen, Beijing, Shanghai and Guangzhou respectively ranked No. 1, No. 3, No. 4 and No. 18 in the world ("The price/income" ratio means the ratio of the average housing price to the average income of local people); 3) The profit of Real estate is very high: Accompanied by high housing prices there is high industry profit. Real estate investment can also share capital appreciation profits from higher prices beyond high industry profit. Therefore, the real estate industry's profit margin is much higher than the real economy sector. Since the housing reform in 1998, the profit margin of the real estate industry has been increasing year by year, from $0 \%$ in 1998 to about $14 \%$ in 2010 . At the same time, though the industrial profit rate has risen, the increasing rate is far less than that of the real estate industry, which remained at around 6\% after 2001. 4) The development of real estate industry depends too much on bank credit. Real estate belongs to capital-intensive industry. From the land transfer, to development and construction, real estate enterprises need a lot of money. Domestic loans, self-financing and other funds are the main sources of funds for real estate enterprises in China. Other funds include deposits, advance receipts and personal mortgage loans. In addition, real estate loans grew faster than average loan growth. By the end of 2016, real estate loans from financial institutions amounted to 26.7 trillion yuan, an increase of $27.0 \%$ over the same period of last year. The loan balance of real estate accounted for $25.0 \%$ of all loans, which was 2.7 percentage points higher than the end of the previous year. In 2016, new real estate loans reached 5.7 trillion yuan, with a cumulative increase of $44.8 \%$ of the total new loans in the same period.

The rapid development of the real estate industry has played a significant role in the economic development of China. On the one hand, the investment in the real estate industry itself can promote regional economic development. On the other hand, the real estate industry has long industry chain and plays the leading role. Therefore, the development of the real estate industry can affect and prompt its upstream and downstream industries (Wang Guojun, Liu Shuixing) [1]. There is no doubt that the booming real estate industry has played a positive role on economic growth and employment expansion. However, when the real estate industry is overheated, its potential harm to the real economy can not be ignored. The rapid rise of house prices in China has attracted attention from all sectors of society. The existing research mainly focuses on the impact of rising house prices on the investment, output efficiency and innovation of enterprises. In theory, the specific impact path includes cost effect, investment crowding-out effect and credit effect, etc. Both the cost effect and the investment crowding-out 
effect have adverse effects on the long-term development of enterprises, and the credit effect will ease the financing constraints of enterprises to some extent. However, some studies have found that the impact of the rising house prices in China is based on cost effect and investment crowding-out effect (Liu, 2016 [2]; Deng, 2014 [3]; Fu, 2017 [4]). So, it is necessary to pay enough attention to the rising house prices.

\section{The Impact of Rising Housing Prices on Investment and Innovation in Business}

The issue of business investment has always been a hot spot for both theorists and practitioners. Housing price fluctuations will have an impact on the company's investment behavior, thereby affecting the investment efficiency and innovation activities of enterprises. We have combed the scientific literature for the impact of housing price fluctuations on business investment and innovation.

As early as 1904, Veloen (1904) pointed out that there was a positive relationship between asset prices and mortgage liabilities. As asset prices rise, the value of collateral owned by the business increases and the business can get more loans from banks or other financial institutions. A large number of macro-literature studied the spillover effect of rising asset prices. Samuelson (1958) [5] established a generational overlap model. In terms of financing agency cost, he studied the influence of bubble economy on economic growth and found that the higher the value of an enterprise's asset, the smaller the cost of its financing agency. When the economic form is more optimistic, the value of corporate assets will increase and the cost of financing agents will decline, thus enterprises can obtain more loans to increase their investment. When the economic form is poor, the opposite conclusion can be reached. Therefore, the temporary impact of asset prices will be magnified and maintained by the market. At macro-economic level, Bowen (1994) [6] pointed out the positive correlation between real estate price and the scale of enterprise investment by using the macroscopic data of UK and USA. Farthi and Titole (2010) [7] assumed in the model that bubbles and external liquidity could be used to ease financing constraints. Enterprises can obtain external funds through asset securitization. When there is a bubble in securitized assets, the prices will be increased and the enterprise's ability to obtain external funds will be enhanced, which will promote the firms' investment. At the same time, they also pointed out that the securitization of asset bubbles will increase the systemic risk. Once the bubble burst, it is easy to induce financial risks. The above research suggests that when the price of the asset that can be used for mortgage bubbles, the value of it will be increased. It means companies can get more loans, which they call the mitigation effect. On the effect of financing mitigation enterprises promote their investment, which is helpful for economic growth and business innovation.

However, empirical studies on the financing mitigation effect of real estate price bubbles are based on the data from developed countries such as the United 
States and Japan. Wu et al (2013) [8] used data from 444 listed companies in 35 cities during 2003-2011. The result showed that the financing mitigation effect did not exist in our country. Miao and Wang's (2012) [9] research based on the endogenous growth model shows that since real estate is a non-productive asset without technological spillover effect, the housing prices rising will lead to speculative bubbles and produce a crowding-out effect on productive investment. This crowding-in effect leads to investment in non-productive assets, which will produce a negative impact on activities and economic growth. The influence mechanism is that the rise of home prices makes the real estate sector returns much higher than others. Because of the capital profit chasing, the industrial capital flows to the real estate market, which seriously squeezes the space of the industrial development. Wang Wenchun and Rong Zhao (2014) [10] also showed that the high return of real estate has attracted many non-real estate enterprises to enter real estate field. The lower the profit margins, the more likely the enterprise will enter the real estate field. Particularly, state-owned enterprises can obtain scarce credit funds at lower cost against the background of soft budget constraints and financial repression. They put a lot of these credit funds into the real estate industry, and then squeeze the investment of research and development into the enterprise, which will negatively affect the innovation activities. Yu Jingwen (2015) [11] found that in the background of rapid growth in house prices and high return on real estate investment, enterprises allocated resources to the real estate sector, thus squeezing R \& D investment with high investment risk and long return period. They also found that the growth rate of house prices increased by 1 percentage point, the proportion of $\mathrm{R} \& \mathrm{D}$ investment in total assets decreased by 0.051 percentage point. Zhang Jie et al. (2016) [12] used provincial-level panel data in China to verify that in those provinces where the faster the real estate investment growth is, the lower the growth rate of $\mathrm{R} \& \mathrm{D}$ investment and invention patent authorization are, which may indicate that the real estate development has a direct hindrance to the innovation activity in the Chinese situation. Second, with the rapid growth of real estate investment, China's financial system has a further inhibitory effect on innovation activities through the biased effect of the term structure of real estate loan.

In general, rising house prices have both positive and negative impacts on the innovation and investment of non-real estate enterprises. On the one hand, the real estate bubbles raise the house prices, and increase the value of land, building and other resources owned by the enterprises, which will alleviate the financing constraints of enterprises, thus facilitating the innovation investment (credit mitigation effect) of enterprises. On the other hand, the real estate bubbles also increase the return on investment of the real estate industry, resulting an investment shift from industrial enterprises to the real estate. Because of the financing constraint, the innovation investment of industrial enterprises is restrained (investment crowding out effect). However, empirical studies in recent years found that the mitigation of financing in China was not obvious, mainly based on the 
effect of investment crowding out. The specific reasons for this are as follows: First, the current situation in our country is that due to the rapid increase of housing prices and the promotion of land prices and rents, the margins between different industries are great. In addition, the economic cycle is in the downward phase and the reverse inhibition has exceeded the positive promotion. The rapid development of the real estate market makes the real estate business profitable and attracts more and more capitals. But the real estate industry generally does not have the technology spillover effect, the investment direction transfer will lead the inhibition to the innovation and the entrepreneurial activity, producing a negative influence to the economic growth. Second, most important enterprises in China are state-owned enterprises. Close ties with local governments and state-owned banks make it easier to obtain capital without any financial constraints (Cull and $\mathrm{Xu}, 2005$ ) [13]. Therefore, state-owned enterprises do not need to use the mortgage loan. Third, the collateral channel mechanism in China can't play the role because of the financial market standards (for example, the controlling lending). Even if private companies are constrained by financing, they cannot get more loans through asset appreciation.

\section{The Impact of Rising House Prices on the Productivity of Enterprises}

Housing prices will not only affect the investment behavior of enterprises, but also further affect the productivity of enterprises output. Chen (2015) [14] found that the rise of housing prices is a vital factor that hinders the sustained and steady growth of economy in China. The reason is that high housing prices will lead to misallocation of resources, reduce the efficiency of resource redistribution and then reduce total factor productivity. Since 2003, as housing prices in China have risen rapidly, both the growth rate of total factor productivity and the efficiency of resource allocation have been declining. Based on the Chinese micro-industrial enterprise database from 2000 to 2007, Chen (2015) [14] found that house prices rose $1 \%$, resource reconfiguration efficiency fell by $0.62 \%$, total factor production rate decreased by $0.45 \%$. The high profit margin caused by high housing prices and the "Upside down" mechanism of total factor productivity is the important reason for the mismatch of resources and the reduction of resource allocation efficiency. Based on the database of China's industrial enterprises, Lu Lingzhi (2016) [15] found that the rise in house prices would cause industrial enterprises to enter the real estate industry, resulting in the decline of industrial production efficiency. It verified the existence of investment crowding out effect and resource mismatch effect.

In theory, rising house prices change the price-ratio relationship between real estate and other goods and factors, increase the present value of real estate stock, expand the money supply and cause changes in the relative profit levels of the industries which have different degrees of connection with real estate. It will cause a cost effect, investment transfer effect, correlation effect, financing effect and distribution effect on industrial sectors. 


\subsection{Cost Effectiveness}

Real estate is one of the important production factors of industrial enterprises. The rise of house price increases the cost of rent or purchase (Gao Bo, 2012) [16], causes the price of land and building materials to rise (Liu Lin, 2013) [17], increasing the cost of plant construction and increasing the cost of industrial enterprises. On the one hand, rising house prices raise the rent for industrial enterprises and increase the production and distribution costs of industrial products. On the other hand, rising house prices increase the cost of living in the labor force, resulting in higher wages. Rising house prices cause the monetary value of real estate to increase. In order to meet the increasing money supply for transaction demand and prevent demand, the money supply must be raised, which will cause the general price level to rise, increase the living expenses of the labor force, resulting in a further rise in labor wages and the labor cost of the industrial enterprises. Rising housing prices increase the cost of industrial enterprises from multiple dimensions and continue to erode the competitive advantage of China's low-cost industries, inhibiting industrial output.

\subsection{Investment Transfer Effect}

The rise in housing prices has led to a rise in real estate investment returns, causing investment funds to real estate and closely related industries, leading to over-allocation of resources in the real estate sector, resulting in the transfer effect of industrial investment. First, the existing industrial enterprises investment funds will be affected by high returns. They will flow into the real estate industry in various forms like shareholding and borrowing, participate in the development of the real estate industry, and reduce the level of industrial investment. Second, the rapid rise in housing prices encourages industrial enterprises to hold more real estate in order to obtain high returns and squeeze industrial investment. Third, the rapid rise in house prices has changed the relative return on investment of the real estate sector and industry sector. As a result, the investment that originally flows into the industry has shifted to the real estate field. It is more and more difficult for the industrial sector to obtain external capital. The effect of investment transfer on industrial investment is unbalanced. The cycle of $\mathrm{R} \& \mathrm{D}$ investment is long and the impact is slow, so the effect in it is greater, Which will affect the innovation capability of industrial enterprises, make the capacity of industrial sustainable development weaken, and form a vicious circle that inhibits industrial output Continued growth.

\subsection{Financing Effect}

The Property prices have led to an increase in the nominal price of assets. The nominal scale of assets expands. Real estate as an important collateral for financing, its prices increasing have led to an increase in the value of collateralized corporate finance, increased the value of collateral for industrial enterprises, promoted corporate to use credit loans, given a premium on the liquidity of debt 
financing and reduced the financing costs, so it is helpful to alleviate the financing constraints of enterprises (Yu Wenjing, 2015; Luo Shikong, 2013) [18]. Rising home prices have led to higher profits for real estate and some closely related industries, increasing the profit opportunities by investing real estate. The real estate industry has a short cycle, quick profits and high returns. Compared with it, industrial investment lacks competitive advantage in the financing market, resulting in a raise in the financing cost of industrial investment and reduction in financing opportunities of industrial investment in the financial market. The rapid rise in housing prices will trigger the need to regulate the real estate market. The central bank will regulate the price level of the money market and the scale of credit, which will increase the cost of using capital in industrial enterprises and make it more difficult to get financing [19].

\subsection{Allocation Effect}

Rising house prices have led to the expansion of asset size, increasing of money supply and higher general price levels. Since the increase speed of prices are unbalanced, the allocation effect is generated. Rising house prices are good for homeowners and real-estate holders, but bad for ordinary Working-class, especially for younger and less educated workers. Since marginal consumption of low-income earners is greater than that of high-income earners, the distribution effect reduces people's demand for industrial products. The rise in house prices has led to an increase in the share of consumer spending. The speculative opportunities brought by the rapid rise in house prices have increased the share of spending on real estate, making consumers less able to pay for goods other than real estate and reducing demand for industrial products. Over a long period of time, housing prices in China monotonous rise. The maintenance and appreciation capacity of real estate are excellent, making it an ideal investment product. In the case of few domestic investment channels, the increase of individual investment in real estate will reduce the demand for industrial products, further strengthen the distribution effect and inhibit industrial output.

To sum up, while rising house prices can both boost the demand for industrial products and promote the growth of industrial output, they also raise the costs for industrial enterprises to use factors of production, squeeze out industrial investment and reduce the demand for industrial products. Under the influence of various forces, rising house prices generally have an inhibitory effect on industrial output.

\section{Summary and Policy Recommendations}

By combing the existing research at home and abroad, it is found that the rising house prices have adverse effects on the development of non-real estate enterprises such as cost effect, investment transfer effect, financing effect and distribution effect and so on. The unbalanced profit margins among industries attract capital to flow into real estate enterprises, and thus affect the innovative activities 
and production efficiency, resulting in a harmful effect on the stable and healthy development of enterprises. Obviously, the thought of trying to boost growth by pushing up prices is unhelpful. To build a long-term mechanism for steady and healthy development of the real estate market and to curb the trend of excessive housing price rise will be of great significance for adjusting the economic structure and promoting economic growth. In order to curb the adverse impact of rising prices on the development of enterprises, we can mainly consider and implement the policies as follows:

- Effectively reduce the housing costs of middle-low income earners, new-employed, non-house workers and migrant workers. Government should be focus on the development of long-term public rental housing, and explore the development of housing subsidies from "subsidies in kind" to "monetary subsidies" in the form of vouchers and accelerate the promotion of common Property rights housing pilot reform.

- Establish and perfect real estate collateral dynamic monitoring mechanism; Determine and adjust the upper limit of real estate collateral timely according to the economic cycle and risk status; Comprehensively and accurately evaluate the value of collateralized real estate, and further regulate and tighten the mortgage loan.

- Control the inflow of credit funds into the real estate field; Set up a monitoring and early warning mechanism for real estate enterprises to invest in the real estate market; Supervise the capital status of the parent companies that have invested in the real estate industry; Prevent and stop the enterprises from using the main business loans for real estate investment.

- Reform the fiscal and taxation system, adjust the fiscal-rights relations at the central level, and reduce the over-reliance of local governments on land transfer payments. At the same time, encourage enterprises to develop their own R \& D capacity, increase the intensity of government R \& D subsidies.

\section{References}

[1] Wang, G.J. and Liu, S.X. (2004) Research on the Driving Effect of Real Estate Industry to Related Industries. Economic Research Journal, No. 8, 38-47.

[2] Liu, B. and Wang, N.J. (2016) Does the Price Increase Squeeze the Export Energy of Our Enterprise? Financial Studies, 42, 53-65.

[3] Deng, B. (2014) The Impact of Real Estate Investment on Enterprise Innovation in Industrial Enterprises-An Empirical Study Based on the Data of Chinese Listed Companies. Economics and Management Studies, 10, 113-120.

[4] Fu, D.P. and Yang, J.Y. (2017) Rising Housing Prices and Industrial Output: Promoting or Suppressing. Economic Restructuring, No. 5, 181-187.

[5] Samuelson, P.A. (1958) An Exact Consumption-Loan Model of Interest with or without the Social Contrivance of Money. Journal of Political Economy, 66, 467-482. https://doi.org/10.1086/258100

[6] Brown, J.R., Fazzari, S.M. and Petersen, B.C. (2009) Financing Innovation and Growth: Cash Flow, Extetnal Equity, and the 1990s R\&D Boom. Journal of Financial Economics, 64, 151-185. https://doi.org/10.1111/j.1540-6261.2008.01431.x 
[7] Farthi, E. and Tirole, J. (2012) Bubbly Liquidity. The Review of Economic Studies, 79, 678-706. https://doi.org/10.1093/restud/rdr039

[8] Wu, J., Gyourko, J. and Deng, Y.H. (2013) Is There Evidence of a Real Estate Collateral Channel Effect on Listed Firm Investment in China. NBER Working Papers, 13(1): 25-36.

[9] Miao, J. and Wang, P. (2012) Sectoral Bubbles and Endogenous Growth. Meeting Papers. Society for Economic Dynamics, 53.

[10] Wang, W.C. and Zhao, R. (2014) Research on the Effect of Rising Housing Price on the Innovation of Industrial Enterprises. Economics: Quarterly, 13, 465-490.

[11] Yu, J.W., Wang, Y. and Tan, J. (2015) High Growth of House Prices and "Low-Tech Lock-In" of Enterprises-Based on the Micro Evidence of China's Industrial Enterprises Database. Shanghai University of Finance and Economics, No. 5, 44-56.

[12] Zhang, J., Yang, L.X. and Fu, X. (2016) Does Real Estate Impede China's Innovation?-An Interpretation Based on the Term Structure of Loans in the Financial System. Management World, No. 5, 64-80.

[13] Cull, R. and Xu, C.L. (2005) Institutions, Ownership, and Finance: The Determinants of Profit Reinvestment among Chinese Firms. Journal of Financial Economics, 77, 117-146. https://doi.org/10.1016/j.jfineco.2004.05.010

[14] Chen, B.K., Jin, X. and Ouyang, D.F. (2015) Housing Prices, Resource Mismatch and China's Industrial Enterprises Productivity. World Economy, No. 4, 77-98.

[15] Lu, L.Z. (2016) Industrial Enterprises to Invest in Real Estate on the Productivity of Enterprises-A Case Study of China's Listed Companies. Southwestern University of Finance and Economics, Chengdu, 1-62.

[16] Gao, B., Chen, J. and Zou, L.H. (2012) Regional Housing Price Differences, Labor Mobility and Industrial Upgrading. Economic Research, No. 1, 66-79.

[17] Liu, L. and Liu, H.Y. (2003) Economic Analysis of the Relationship between Land Price and House Price. Journal of Quantitative \& Technical Economics, No. 7, 27-30.

[18] Luo, S.K. and Zhou, Y.H. (2013) How Prices Affect Business Investment? Theoretical and Empirical. Financial Research, 39, 133-144.

[19] Mao, F.F. (2008) Power Transmission Mechanism Affecting House Price Fluctuation: From the Perspective of Labor Cost. Policy Theory and Practice, No. 7, 42-43. 